(Re) descrevendo Foucault

\title{
(RE)DESCREVENDo Foucault: COM RoRTy, CONTRA RORTY ${ }^{1}$
}

\author{
Felipe Quintão de Almeida ${ }^{2}$ \\ Alexandre Fernandez $\mathrm{Vaz}^{3}$
}

RESUMO: O artigo propõe uma interlocução entre o filósofo francês Michel Foucault e o filósofo norte-americano Richard Rorty. Apresenta a descrição que Rorty realizou do colega francês. Analisa essa leitura e oferece, a partir do próprio Foucault, uma interpretação alternativa, que aponta para algumas imprecisões cometidas por Rorty, em sua interpretação. Conclui com um comentário sobre a conversação proposta.

PALAVRAS-CHAVE: Rorty. Foucault. Filosofia. Política

\section{INTRODUÇÃo}

O filósofo francês Michel Foucault e o filósofo norte-americano Richard Rorty são duas referências importantes no cenário acadêmico, exercendo influência não apenas em seus campos de origem, mas, também, em outras áreas, como a psicanálise e a educação. O interesse pela obra de Foucault, no Brasil, é anterior ao dedicado a Rorty, desenvolvendo-se, desde a década de 1960, uma tradição de estudo do seu pensamento entre nós. Há várias obras de Foucault publicadas no Brasil, assim como um sem número de comentários e interpretações em livros, artigos, dossiês, dissertações, teses e coletâneas, cuja origem se deve aos muitos colóquios sobre ele. ${ }^{4}$ Por outro lado, o livro mais conhecido de Rorty, A filosofia e o espelho da natureza, somente em 1994 recebeu tradução para o português, quinze anos após seu lançamento, em 1979. Desde aquela publicação, porém, o filósofo estadunidense tem reunido, em solo brasileiro, pessoas interessadas na análise de

\footnotetext{
1 Trabalho realizado com apoio do CNPq.

2 Doutor em Educação pela Universidade Federal de Santa Catarina (CED/UFSC). Professor do Programa de Pós-Graduação em Educação Física da Universidade Federal do Espírito Santo (CEFD/ UFES). Laboratório de Estudos em Educação Física (LESEF/CEFD/UFES) e Núcleo de Estudos e Pesquisas Educação e Sociedade Contemporânea (CED/UFSC). fqalmeida@hotmail.com.
}

3 Doutor pela Leibniz Universität Hannover; professor dos Programas de Pós-Graduação em Educação e Interdisciplinar em Ciências Humanas da Universidade Federal de Santa Catarina (UFSC); coordenador do Núcleo de Estudos e Pesquisas Educação e Sociedade Contemporânea (CED/ UFSC); pesquisador CNPq. alexfvaz@uol.com.br.

4 Em 2009, realizou-se, no Rio de Janeiro, o VT Colóquio Internacional Michel Foucault. 
seu trabalho, o que favoreceu a tradução de outras obras bem como a criação de fóruns específicos para discussão de sua filosofia. ${ }^{5}$

Propomos, neste artigo, apresentar uma interlocução entre os dois filósofos. Ambos, quando em vida, não fizeram isso, ${ }^{6}$ ainda que Foucault tivesse lecionado nos Estados Unidos. O que temos disponível, por um lado, são textos do filósofo norte-americano descrevendo o filósofo francês e, por outro, analisando o que aquele, em vários escritos, chamou de esquerda cultural, orientação política que encontrou na filosofia de Foucault uma importante referência, ao menos em solo norte-americano. Para desenvolver nosso objetivo, apresentamos, inicialmente, a interpretação que Rorty realizou do seu colega. Na sequência, oferecemos uma leitura alternativa, cotejando o vocabulário rortiano, àquele respeito, com o nosso próprio. Encerramos com um rápido comentário sobre a conversação proposta.

\section{Descrevendo Foucault, com Rorty}

Rorty estabeleceu com Foucault uma relação ambígua. Há nele uma leitura mais favorável e outra cética em relação aos (ab)usos da esquerda americana quanto à obra de Foucault. Uma maneira de demonstrar aquela primeira interpretação é tomar em conta as aproximações que ele identificou entre Foucault e Dewey. O resultado disso foi que Rorty (1999a, 1999b) concebeu a filosofia foucaultiana como uma versão atualizada do trabalho de Dewey, pois o francês teria feito, após a virada linguística, o que o americano estivera fazendo da filosofia, antes desse movimento de inflexão. Rorty também admira Foucault naqueles aspectos em que sua filosofia oferece um contraponto aos vocabulários que ele próprio desdenha. Assim, ele observa Foucault como uma inspiração, porque sua filosofia também dispensa os discursos universalistas e fundacionistas de toda ordem, é avessa às posturas favoráveis ao antirrelativismo e recusa conceber a discussão moral no âmbito das éticas deontológicas. É, além disso, mais sensível à causa ironista do que outros filósofos (como Habermas), porque seu historicismo e nominalismo ajudam a nos tornarmos mais brincalhões, livres e inventivos, relativamente à nossa escolha de autodescrição. Essas afinidades, contudo, não tiveram muito espaço na letra de sua filosofia, já que nela predominou o tom crítico dirigido a Foucault. Comecemos a ver isso, tomando em análise o que, segundo o próprio Rorty, é comum a ambos: a ironia filosófica.

\footnotetext{
5 O exemplo mais recente disso é a realização do I Colóquio Internacional Richard Rorty, em 2009, também no Rio de Janeiro.

${ }^{6}$ Só conhecemos um comentário de Foucault a respeito de uma crítica que Rorty faz a ele. Conferir o texto Polêmica, política e problematizações (FOUCAULT, 2004a). 
$\mathrm{Na}$ obra de Rorty, ela corresponde àquele exercício de autocriação permanente, em que os indivíduos se concentram em suas obrigações consigo próprios, sem se preocupar com os efeitos de suas ações sobre os demais. Trata-se, para ele, de uma tarefa eminentemente privada, porque Rorty (2007) defende uma rígida distinção entre a esfera privada, reino do ironista, e a esfera pública, terreno de outro tipo de pessoa: o liberal. Segundo ele, não deveríamos ter que escolher entre um tipo de pessoa e outro, mas seria importante tratar as demandas por autocriação e solidariedade humana como igualmente válidas, embora incomensuráveis entre si. Rorty é muito direto em seu recado: os filósofos deveriam reconciliar-se com a cisão entre o privado e o público, em seus vocabulários finais. Ainda conforme ele, a democracia liberal é a forma de vida que possibilitou a convivência desses dois jogos de linguagem (público e privado), e Rorty não vê motivos de modificá-los. E não há possibilidade de que a filosofia, ou qualquer outra disciplina teórica, possa, algum dia, produzir uma reconciliação forçada entre ambos, muito menos dizer que um teria prioridade epistêmica sobre o outro.

A expectativa rortiana era a de que Foucault pudesse conciliar, ao invés de sintetizar, o senso privado da identidade do ironista com suas esperanças liberais, ou seja, que pudesse conciliar, como o próprio Rorty fez, a contingência da reinvenção de seu próprio eu com as necessidades dirigidas ao bem comum, como a justiça, a decência e a liberdade de todos. Foucault, na interpretação de Rorty, não foi capaz disso, pois quis, em alguns momentos, ver sua própria autonomia privada refletida ou encarnada nas instituições sociais. Em tais circunstâncias, é o privado que acabou adentrando ao público, ao político, e não o contrário. Como Foucault, na descrição de Rorty, borra essa distinção, ele receia que a busca da autonomia, uma demanda meramente privada, sacrifique a manutenção da solidariedade, isto é, que a busca pela felicidade individual comprometa a lealdade ampliada (a justiça), transformando o ironista liberal em alguém cego e surdo à dor do outro, indisponível ao sofrimento alheio, uma vez que mais preocupado com seu vocabulário final (sua constante autodescrição) do que com o vocabulário que provoca dor ao outro. Ele reprova em Foucault a pretensa indiferença social de seu modelo estético da existência, pois interpreta que o cuidado de si dispensaria o cuidado do outro. Essa é a assunção que, "[...] a não ser que alguma ligação interessante entre aquilo que mais interessa um indivíduo e as suas obrigações morais para com os próximos, ele não tem tais obrigações" (RORTY, 1999a, p. 307).

Nessas circunstâncias, o ironista deixa de considerar seu lado liberal, porque sua preocupação com a experimentação individual (e só com ela) faz dele algo inútil para fins públicos, para uma política reformista e social. Daí Rorty dizer que Foucault é um filósofo útil e maravilhoso, desde que sua obra seja utilizada do ponto de vista privado. Não surpreende a conclusão a que chega: “[...] privatize 
a tentativa nietzschiana-sartriana-foucaultiana de autenticidade e pureza, para impedir que se resvale para uma atitude política que o leve a achar que existe uma meta social mais importante do que evitar a crueldade” (RORTY, 2005, p. 123). Para o norte-americano, ao contrário, as sociedades

[...] não são quase-pessoas, são (no seu melhor social democrático, liberal) compromissos entre pessoas. O objetivo de uma sociedade liberal não é inventar ou criar qualquer coisa, mas simplesmente tornar o mais fácil possível às pessoas atingirem os seus diferentes alvos privados sem se magoarem mutuamente. Numa sociedade liberal, as nossas relações com os nossos concidadãos não é suposto serem românticas ou inventivas; é suposto terem a inteligibilidade rotineira do mercado ou do tribunal. (RORTY, 1999a, p. 306).

Concebida dessa maneira a sociedade liberal, Rorty considera que Habermas e também Dewey, grandes filósofos públicos (embora pouco úteis, na dimensão privada), têm muito mais a contribuir com esta organização social do que Foucault. Isso se explica porque, no vocabulário daqueles dois filósofos, Rorty consegue encontrar muito mais espaço para a esperança injustificada e para um sentido de solidariedade humana, se comparado com o discurso de Foucault, que parece não deixar muita saída para os sujeitos, pois sua filosofia, na interpretação de Rorty (1999a), está impregnada por uma ambiguidade incapacitante entre o poder como um termo pejorativo e o poder como um termo neutro e descritivo. No primeiro sentido, poder pertence a um campo semântico do qual verdade e liberdade não podem ser excluídos. Na segunda conotação, ele acha que o termo possui o sentido vazio com o qual Nietzsche empregou o termo vontade de poder. Nessa concepção, o estudo de qualquer tema será um estudo das estratégias de poder, reconhecida sua ubiquidade malevolente,

[...] tão imperceptível e insistente quanto um fantasma engenhoso". Em seu uso foucaultiano, o termo "poder" denota uma agência que tem deixado uma mancha indelével sobre toda palavra em nossa língua e sobre toda instituição em nossa sociedade. Ela sempre estará lá, mas não se pode vê-la chegando ou partindo. Alguém pode ver um portador de propina de alguma corporação chegando no escritório de um deputado, e talvez até impedi-lo de entrar. Mas ninguém pode impedir o poder, no sentido de Foucault. O poder está tanto dentro quanto fora de alguém. Está mais perto que as mãos e os pés. Como Edmundson disse: "não se pode confrontar o poder; só se pode encontrar seus inconscientes e geralmente temporários agentes... [ele] tem capacidades de movimento e transformação que o tornam uma força sobrenatural" (ibid., p. 42). Somente interminável auto-análise individual e social, e talvez nem mesmo isso, pode ajudar-nos a escapar das malhas infinitamente finas da sua teia invisível. A ubiqüidade do poder foucaultiano é reminiscente da ubiqüidade do Satã, e assim da ubiqüidade do pecado original - aquela mancha diabólica em toda alma. (RORTY, 1999c, p. 130-131). 
A partir da leitura do que o poder pode fazer conosco, Rorty acredita que fica bastante difícil admitir, com Foucault, que as mudanças que aconteceram nas instituições sociais europeias dos últimos trezentos anos também fizeram diminuir o sofrimento das pessoas e, ao mesmo tempo, aumentaram a possibilidade de elas conduzirem suas vidas de maneira mais autônoma. Rorty entende que Foucault participa da "cultura do ressentimento", ou seja, da corrente intelectual que procura negar, subestimar ou minimizar o progresso moral alcançado pelas democracias liberais do Ocidente. Ao contrário dessa tradição, o filósofo estadunidense não pensa que existe algo de inerentemente repressivo na sociedade como tal, do mesmo modo que não vê qualquer problema em usar aquilo que Foucault chama de biopoder, para aculturar os sujeitos. Tampouco haveria algo de errado em usar redes de poder para moldar pessoas em indivíduos com senso de responsabilidade moral, já que "Poder' e 'cultura' são indicações equivalentes das forças sociais que nos convertem em mais do que animais" (RORTY, 1999b, p. 285). Rorty considera mais importante maximizar tanto essas forças sociais que nos "[...] convertem em mais do que animais" quanto a tolerância com a excentricidade e com os desvios individuais. Nesse sentido, vê no binômio saber-poder não apenas um instrumento para a implantação de uma engenharia disciplinar ou de controle, mas também uma conexão interessante entre o conhecimento e a solidariedade humana. Ele entende que faltou a Foucault esse tipo de avaliação do poder, sendo o resultado visível em sua descrição negativa da modernidade capitalista ${ }^{7}$ como uma sociedade panóptica, em que a individualidade se tornou impossível pela dinâmica dos saberes e dos poderes normalizadores. Porque a retórica da emancipação está ausente de seu trabalho, Rorty (1999a) pensa que Foucault foi extremamente maléfico ao espírito reformista, que até seu surgimento caracterizara o pensamento de esquerda em seu país.

Não surpreende que o filósofo (1999c, 2000) tenha feito uma dura crítica aos desafortunados (ab)usos feitos de Foucault, na América, sendo que o resultado mais evidente dessa influência teria sido o retrocesso de uma esquerda com caráter reformista e consensual e a ascensão de uma esquerda de caráter cultural, mais preocupada em denunciar os traços (fa)logocentristas da sociedade americana, o casamento do saber com o poder, a tecnocracia, entre outras faces do mesmo processo, do que interessada em melhorar o próprio sistema. Segundo o filósofo norte-americano, essa mudança no interior da esquerda correspondeu à substituição de uma perspectiva programática e caracterizada por seu ativismo político por outra desgostosa, de meros espectadores, cuja principal marca seria a desesperança, pois, ao invés de tomar a política conforme o espírito democrático

\footnotetext{
7 Rorty (1999a, p. 271) chegou mesmo a dizer que o trabalho de Foucault, visto desse ângulo, poderia ser " $[. .$.$] facilmente encarado como reinventando a sociologia 'funcionalista' americana".$ 
e liberal, passou a encará-la com um espírito de profundo pessimismo ou de fúria revolucionária.

Rorty viu Foucault como um cidadão que voltou as costas para as esperanças sociais das sociedades liberais, um indivíduo desapaixonado em relação à presente ordem social. No extremo, alguém que não acreditou na possibilidade da esperança como tal, sendo mais fácil encontrar em sua face um desdém cínico e ressentido. Sua recusa em não participar do "sistema" correspondeu à indisposição para melhorá-lo, para fazer as coisas de modo diferente. Para expressar essa interpretação, Rorty (1999a) reproduziu, mais de uma vez, a seguinte passagem de Foucault: "[...] imaginar outro sistema é estender a nossa participação no sistema presente" (FOUCAULT apud RORTY, 1999a, p. 303).

O filósofo americano lamenta que as narrativas históricas de Foucault não ofereceram a ele um ponto de apoio para comparar o presente em que vivemos com a aculturação em que nossos avôs e nossas avós foram socializados; da mesma forma, não possibilitaram a ele a proposição de alternativas concretas de como evitar os erros de ontem, na socialização atual. Ao contrário, elas reforçam a compreensão incrédula e horrorizada de que a verdade (o saber) e o poder são inseparáveis e que não há como escapar disso. Isso o teria levado, para Rorty, a um quase anarquismo, concluindo que toda instituição social é injustificável e serve ao poder normalizante, reproduzindo o sempre mesmo, o sempre igual.

A desesperança política, todavia, não é a única herança funesta que Rorty associa aos escritos de Foucault. Outra consequência da presença de Foucault entre os esquerdistas americanos teria sido a indesejável inflação teórica da atividade política. Desde então, os membros dessa esquerda passaram a querer que suas competências no plano estritamente teórico (filosófico, literário, sociológico etc.) fossem de alguma utilidade direta para se obter objetivos políticos. Nessas circunstâncias, quanto mais alto fosse o grau de abstração, quanto mais rebuscado o aparato conceitual, mais radical seria a crítica e a possibilidade de reverter a ordem estabelecida. O resultado dessa tendência, sempre conforme Rorty, é que o antigo utopismo da esquerda reformista e consensual cedeu lugar a uma esquerda academicista, primeiramente preocupada em teorizar e só mais tarde em abordar utopias políticas. Ele avalia que, nesse movimento, a esquerda de seu país teria perdido grande parte da utilidade obtida pela velha esquerda:

[...] uma gama de energia dos intelectuais de esquerda na academia americana contemporânea foi desperdiçada, exatamente à medida que eles passaram a esperar que as obras no interior de disciplinas tais como filosofia e a crítica literária pudessem ser engrenadas com a ação política por meio de alguma via direta (enquanto oposta a uma via de longo curso, atmosférica, indireta). Um dos sintomas dessa esperança é a convicção de que é politicamente proveitoso 


\begin{abstract}
"problematizar" ou "colocar em questão" conceitos, distinções instituições tradicionais. Meu próprio ponto de vista é o de que não há muito proveito em apontar as "contradições internas" de uma prática social ou "desconstruí-la", a não ser que se possa advir com uma prática alternativa - a não ser que se possa por fim traçar uma utopia, na qual o conceito ou distinção se tornariam obsoletos [...]. Minhas dúvidas acerca da esquerda foucaultiana contemporânea dizem respeito à sua capacidade para oferecer tais visões e tais sugestões. (RORTY, 1997, p. 29-30).
\end{abstract}

Além de seu pessimismo libertário e de seu teoricismo exagerado, a nova esquerda americana desaponta Rorty, na medida em que toma as questões culturais como eixo da luta política. O resultado desse processo teria sido a implosão, não somente na esquerda americana, de movimentos políticos centrados em tópicos como a identidade, a diferença, o reconhecimento etc. Apesar de admitir a importância desses movimentos políticos, não é difícil perceber o ceticismo que ronda os comentários do filósofo a respeito dessa estratégia política. Há pelos menos duas maneiras de expor essa indisposição. Em primeiro lugar, Rorty entende que os movimentos de reconhecimento baseados na dimensão cultural deveriam ser tributários de uma organização do político, cujo foco fosse o que um indivíduo, em determinado país, tem em comum com todos os outros, não a sua diferença específica, a sua alteridade em relação a todos os demais. Rorty (1999c) nos dá um exemplo a esse respeito. Segundo ele, quando a esquerda reformista anterior aos anos 1960 discutia sobre a situação das minorias oprimidas em seu país (os negros, os homossexuais ou os imigrantes), fazia isso proclamando que todos, em suas múltiplas diferenças, eram americanos, e que deveriam se respeitar como tais. As diferenças de cada um pouco importavam, quando comparadas com a identidade de todos como companheiros americanos. Se não incentivava o orgulho da diferença, essa esquerda, contra o conservadorismo corrente, tampouco o condenava. A única diferença que realmente importava, do ponto de vista político, era o fato de ser americano, independentemente se fosse afroamericano, hispano-americano, gay, lésbica ou negro. Ter orgulho de sua diferença

[...] é uma resposta inteiramente razoável para a sádica humilhação a que alguns têm sido sujeitados. Mas na medida em que esse orgulho impeça alguém de também ter orgulho por ser um cidadão americano, por pensar em seu país como sendo capaz de reforma, ou de ser capaz de unir-se aos heterossexuais ou aos brancos em iniciativas reformistas, é um desastre político. (RORTY, 1999c, p. 137).

Sua aposta, por um lado, é que esses esquerdistas possam colocar essas teorias da diferença em moratória (o que significa dizer parar de elaborar filosofias sobre elas) e, por outro, também pudessem mobilizar o que ainda resta do 
orgulho de norte-americano, o que equivale à elaboração de políticas baseadas nessa identidade que engloba todas as outras, respeitando-as em suas diferenças.

O antiamericanismo e/ou antietnocentrismo da esquerda cultural, portanto, explicam parte da recusa de Rorty em relação às políticas culturais centradas na identidade e na diferença. Existe, como mencionamos, outra razão. Rorty trabalha com a ideia segundo a qual a nova esquerda deixou de discutir sobre aquilo que é, para ele, essencial na atualidade: dinheiro e mercado de trabalho. Segundo o filósofo (1999c, 2006), a esquerda cultural pensa mais sobre o estigma e a diferença do que em nos oferecer uma crítica da economia política, de sorte que ela teria se tornado pouco útil para se refletir sobre os desafios e as consequências políticas da globalização econômica entre os brancos, os negros, os homossexuais, os hispanos etc. À sua maneira reformista, consensual e antianticapitalista, ele quer renovar a agenda política de seu País, propondo que a esquerda "[...] teria que falar muito mais sobre dinheiro, mesmo que para isso tivesse que falar menos sobre estigma [diferença, identidade]" (RORTY, 1999c, p. 128). Isso significa que as questões políticas centrais não deveriam ser buscadas no terreno das diferenças culturais ou identitárias entre as pessoas, mas, sim, na desigualdade financeira e de oportunidades entre elas. Em outras palavras, o que Rorty sugere é que as distinções entre as tradições culturais não são uma boa saída para orientar as decisões políticas que precisamos tomar, no sentido de diminuir o sofrimento e a crueldade na sociedade atual. Nesse quesito, ele chega mesmo a dizer que os marxistas continuam tendo alguma razão e sugere que as atenções políticas da esquerda deveriam se concentrar no retorno à chave da luta de classes:

The best thing that could happen to the American left would be for the
academics to get back into the class struggle, and for the labour union members
to forgive and forget the stupid and self-defeating anti-American rhetoric that
filled the universities of the late sixties [...]. Nevertheless, leftist academic
politics has run its course. It is time to revive the kind of leftist politics that
pervaded American campuses from the Great Depression through to the early
sixties - a politics that centres on the struggle to prevent the rich from ripping
off the rest of the country. If the unions will help us revive this kind of politics,
maybe the academy and the labour movement can get together again. Maybe
together we can help bring our country closer to the goal that matters most: the
classless society. That is the cause for which the American Federation of Labor
and Congress of Industrial Organizations organizers are now fighting, and for
which some of their predecessors died. (RORTY, 1999d, p. 260-261).

Em sua avaliação, a esquerda cultural não tem feito muito para expandir essa mudança de pensamento. Ela não tem se esforçado para que os indivíduos passem a pensar nas oligarquias ou "[...] nos patrões como o inimigo" (RORTY, 2006, p. 55), ao invés de seguir insistindo que a luta reside na identidade cultural 
ou na diferença cultural alheia. Ela continua realizando seus estudos sobre os homossexuais, os negros, os hispano-americanos etc., ao invés de organizar mais pesquisas sobre os desempregados, os sem-teto ou os moradores de trailers, todos eles vítimas, em maior ou menor grau, dos efeitos da globalização sobre o mercado de trabalho. Esse tipo de investigação, na interpretação de Rorty, deixou de ser atraente, pois eles, os desempregados e os sem-teto, não são os "outros" ou a "minoria" no sentido relevante para a esquerda cultural. Para ser “[...] este 'outro' neste sentido você precisa carregar um estigma inerradicável, que faz de você uma vítima do sadismo socialmente aceitável ao invés de uma vítima do mero egoísmo econômico" (RORTY, 1999c, p. 117). Na medida em que essa transformação não acontece, ou seja, enquanto a esquerda cultural não se reconcilia com a antiga esquerda reformista, aumenta a desigualdade, a insegurança e a crescente proletarização dos norte-americanos, um cenário que se estende também às demais partes da sociedade globalizada - e visível especialmente agora, em tempos de crise econômica mundial.

Com o apelo de Rorty à necessidade de reconduzir a luta de classes ao cerne do debate político contemporâneo, encerramos este tópico. No próximo, analisamos essa leitura que Rorty oferece de Foucault. Suspeitamos, na esteira de Marshall (1994) e de Costa (1995), que Rorty possa ter cometido alguns desserviços a Foucault, operando uma leitura parcial (reducionista?) do colega francês. A estratégia, para tanto, é tomar em análise alguns pontos levantados pelo filósofo estadunidense a respeito de Foucault e fazer o exercício de colocá-los sob a tensão da letra da filosofia de quem se descreve.

\section{Redescrevendo Foucault, CONTRa Rorty}

Consideremos, neste início, a maneira pela qual Rorty descreveu o conceito de poder em Foucault. Parece predominar a leitura do poder como coisa maligna, fantasma de cuja influência não se pode escapar. Isso é tudo que podemos concluir a respeito do poder em Foucault? Teria ele reduzido toda produtividade e positividade do poder aos seus estados de dominação? Todo seu trabalho histórico-filosófico teria servido somente para nos dizer que não há escapatória de uma aculturação repressiva? Ele olhou para a aventura moderna e somente descreveu o poder opressor e repressor exercido por uma racionalidade política, cujo poder incidiria sobre a vida? Não é possível resumir o trabalho de Foucault a esse tipo de interpretação. Não é difícil chegar a essa conclusão, na medida em que encontramos em escritos do filósofo francês outras conotações para esse mesmo conceito. Tomemos o caso de Vontade de saber, volume inicial da trilogia História da sexualidade, publicado em 1976 - portanto, somente um ano 
após Vigiar e punir (e antes mesmo de Rorty escrever seu primeiro texto a respeito de Foucault, em 1981).

No tópico dedicado ao método desse empreendimento, Foucault interroga o poder, seus dispositivos e suas práticas, não sob a forma da unidade global da dominação e da sujeição, que são, antes de tudo, suas formas terminais, mas, sim, a partir da capacidade de transformação que todo exercício de poder implica, quer dizer, uma “[...] multiplicidade de correlações de forças imanentes ao domínio onde se exercem e constitutivas de sua organização; o jogo que, através de lutas e afrontamentos incessantes as transforma, reforça, inverte [...]" (FOUCAULT, 1997, p. 102). O que se torna central são os combates e as lutas inerentes às relações de poder, não apenas a descrição das enormes articulações institucionais e políticas que formam as estruturas de poder. Essas correlações de força são guerras anárquicas de desestabilização infinita dos mecanismos de poder: são relações antagonistas, de estratégias, de enfretamento, de combate.

Nessa fórmula sobre as relações de poder, não há poder sem recusa ou desacordo em potencial. No argumento de Foucault, já não existem mais relações de poder que sejam completamente triunfantes, assim como tampouco a dominação é incontornável. Linhas de fuga possíveis são traçadas, permitindo aos indivíduos lutar contra os abusos do poder. Isso significa que onde aquelas relações existirem, haverá decerto resistência, pois, se não houvesse possibilidade alguma dela, relações de poder não estariam em jogo. Elas não podem existir senão em função de uma multiplicidade de pontos de resistência que se apresentam como o outro, na relação de poder, inscrevendo-se como interlocutores irredutíveis. Essa relação de incitação recíproca cessa, quando o ambíguo e móvel jogo das relações de poder é substituído por aquilo que Foucault chamou estados de dominação. Embora estes sejam instrumentos e efeitos daquelas relações, não constituiriam seu princípio ou sua natureza, como podemos supor na interpretação que Rorty faz da presença do conceito de poder em Foucault.

Este filósofo, todavia, não parou por aí, desenvolvendo a passagem desse modelo belicoso de poder, com forte inspiração nietzschiana, ao modelo da conduta. A arte de conduzir os outros e a si próprio fez das relações de poder muito menos da ordem do afrontamento entre dois adversários (como na guerra) do que da ordem do governo. O modo de relação próprio ao poder " [...] não deveria, portanto, ser buscado do lado da violência e da luta, nem do lado do contrato e da aliança voluntária (que não podem ser mais do que instrumentos); porém, do lado deste modo de ação singular - nem guerreiro nem jurídico - que é o governo" (FOUCAULT, 1995, p. 244). Concebido em um sentido amplo e anterior à 
captura que a ciência política fez dele, desde os séculos XVII e XVIII, ${ }^{8}$ o governo corresponde à atividade de conduzir (não ditar, comandar ou reinar) os indivíduos ao longo de suas vidas, colocando-os sob a autoridade de um guia ou um mestre da existência, que é responsável pelo que aqueles fazem ou pelo que acontece com eles. Seu traço distintivo seria que alguns homens, sem recorrer à coerção ou à repressão, podem determinar o governo de outros homens. Governar seria, assim, a estruturação do eventual campo de ação dos outros: um modo de ação sobre ações. Governar consiste em conduzir condutas, que têm por objeto a conduta de outro indivíduo ou de um grupo. Conforme o próprio Foucault (2005, p. 327): "Se eu digo a verdade sobre mim mesmo como eu o faço, é porque, em parte, me constituo como sujeito através de um certo número de relações de poder que são exercidas sobre mim e que exerço sobre os outros." Definida como ação sobre outros e a si próprio, Foucault (1995) atrela no coração mesmo de toda relação de poder a liberdade. O poder só se exerce em sujeitos potencialmente livres e enquanto assim permanecerem. Não há qualquer relação de confronto e exclusão entre poder e liberdade, contudo, um jogo mais complexo, no qual a liberdade aparece como uma condição de existência do poder.

Não que o próprio Rorty achasse que o poder fosse o mal, sinônimo da dominação. Isso está claro, por exemplo, quando comenta que, à semelhança da cultura, é o poder o que nos transforma em algo mais do que em simples animais. Ou, então, quando afirma não ver qualquer perigo com a noção de biopoder. Faltou a ele, todavia, uma maior atenção aos deslocamentos da obra foucaultiana, o quais se iniciam, como dissemos, antes mesmo de Rorty escrever seu primeiro texto sobre Foucault. Assim, enquanto ele só conseguiu ver em Foucault a vontade de um poder sobre a vida, nossa redescrição "olha" para Foucault e vê em sua obra o poder também como vontade de liberdade, como vontade de resistência, como governo, como algo além da pura e simples dominação. Interpretado dessa maneira, não há motivo para lamentar sua ubiquidade satânica, como sublinhou Rorty, mas felicitar sua presença, pois, onde ele se encontra, a liberdade o acompanha, sempre à espreita. Só assim o outro poderia ser concebido e mantido até o fim como sujeito da ação, como sujeito ativo que é capaz de influenciar a conduta do outro (FOUCAULT, 1995).

Os deslocamentos operados por Foucault dispõem, no cerne de sua perspectiva, o problema da vontade individual. É a partir desse momento que, em

8 Em Segurança, território e população Foucault (2008a) analisa como a governamentalidade se resumiu aos fenômenos relativos ao Estado. O filósofo nos mostra como as relações de poder foram paulatinamente governamentalizadas, quer dizer, racionalizadas e centralizadas, na forma das instituições do Estado. É partir dessa operação que novas questões se colocam para o Estado, que passa a ter na população seu objeto, na economia seu saber mais importante e nos dispositivos de segurança seus mecanismos básicos. 
sua obra, um complexo conjunto de práticas de subjetivação ou tecnologias do eu, distintas substancialmente da objetivação característica das tecnologias disciplinares, torna-se a preocupação central do filósofo: “[...] como constituímos diretamente nossa identidade por meio de certas técnicas éticas de si, que se desenvolveram desde a Antiguidade até nossos dias?" (FOUCAULT, 2004a, p. 302). É o que se poderia chamar, como Foucault o faz, de uma arte da existência ou de uma estética da existência: "Trabalho de si para consigo, elaboração de si para consigo, transformação progressiva de si para consigo em que se é o próprio responsável por um longo labor que é o da ascese (áskesis)" (FOUCAULT, 2004b, p. 20).

Essa nova orientação nos oferece outro motivo para ficar com ele contra a leitura que Rorty oferece a seu respeito, pois, embora partilhe com o intelectual ironista do estadunidense a dúvida radical dos vocabulários finais, o esteta da existência teorizado por Foucault não compreende, como Rorty supõe, uma tarefa eminentemente privada. Ao contrário do ironismo, em Foucault, a atividade consagrada a si mesmo não constitui um exercício de solidão, realizando-se em uma esfera alheia à vida na cidade, mas um modo de viver junto, uma verdadeira prática social, porque não existe autoestilização na solidão. $\mathrm{O}$ cuidado de si apresenta-se como uma verdadeira intensificação das relações sociais, já que o governo de si implica necessariamente a relação com outros, dando lugar a relações interindividuais, a trocas e comunicações, integrando uma prática dos governos dos outros, pois nisso também reside a arte de governar. ${ }^{9}$ A cultura de si é menos uma escolha oposta à atividade política, econômica, familiar, cívica etc., como sugere a interpretação de Rorty, do que uma tentativa de manter essas atividades no limite e nas formas consideradas convenientes.

Torna-se claro, dessa maneira, que a inflexão foucaultiana em direção ao sujeito ativo que cuida de si próprio para cuidar melhor dos outros não constitui a celebração de um individualismo hedonista (o culto californiano de si) e muito menos um declarado descompromisso político em relação ao restante da sociedade. O fato de Foucault atrelar o cuidado de si ao cuidado do outro é prova mais do que suficiente para evitar o receio rortiano segundo o qual a indistinção

\footnotetext{
${ }^{9}$ Dizer que nisso de igual forma reside a arte de governar significa afirmar que a governamentalidade não se resume às disciplinas, à biopolítica, à razão de Estado, à política ou ao liberalismo, mas também envolve as diferentes formas de ascese (antiga, cristã) e os cuidados de si. A reflexão foucaultiana da governamentalidade, desse modo, engloba o estudo do governo de si (ética), o governo dos outros (as formas políticas da governamentalidade) e as relações entre ambos. Com esse movimento, Foucault quer ver ampliada a noção de governo, privilegiando, em seus escritos mais tardios, o governo de si (em vez de do governo da família ou do Estado), e oferecendo uma visão precisa de que, no cuidado de si no pensamento dos filósofos antigos, dos estóicos e dos cínicos, encontra-se, como condição ontológica, o pressuposto do cuidado dos outros.
} 
entre uma esfera pública e outra privada transformaria a estética da existência (a ironia, nos termos de Rorty) no objetivo supremo da política, sendo o risco a se pagar por isso o descompromisso com os outros cidadãos da sociedade liberal, a falta da solidariedade social, a indiferença em relação à dor e ao sofrimento alheios. Nada no pensamento de Foucault sugere desrespeito à dor do outro ou alheamento diante da opressão. Ao contrário, Foucault acredita que essa solidariedade e esse compromisso são reforçados com o cuidado de si, que é, ao mesmo tempo, um cuidado do outro.

Foucault sublinhará, em várias passagens, a necessidade desse vínculo intersubjetivo. São como duas vias de acesso inversas para uma mesma questão: “[...] como se constitui uma 'experiência' em que estão ligadas a relação consigo mesmo e a relação com os outros" (FOUCAULT, 2004a, p. 242-243). Logo, é por isso que a racionalidade do governo dos outros é idêntica à racionalidade do governo de si: para ser um bom governante, é preciso primeiro governar a si próprio, controlar apetites, desejos e fantasias, pois é o poder sobre si que vai regular o poder sobre os outros. Trata-se de uma condição pedagógica, ética, mas também ontológica, para a constituição de um bom governante: “[...] ocupar-se consigo para poder governar, e ocupar-se consigo na medida em que não se foi suficiente e convenientemente governado" (FOUCAULT, 2004b, p. 57).

À diferença de Rorty, portanto, Foucault advoga que a resistência às formas dominantes do poder político, na atualidade, passa necessariamente pela relação de si consigo, ou seja, exatamente pela dimensão privada da vida, que, na filosofia de Rorty, seria alheia ao discurso público. Assim concebida, a análise do que Foucault chama de governamentalidade não pode prescindir, teórica e praticamente, do movimento de um sujeito que seria definido pela relação de si para consigo mesmo. Isso significa que devemos considerar "[...] que as relações de poder/governamentalidade/governo de si e dos outros/relação de si pra consigo compõem uma cadeia, uma trama e que é em torno destas noções que se pode, a meu ver, articular a questão da política e a questão da ética" (FOUCAULT, 2004b, p. 307).

Interpretada dessa maneira a relação entre o privado e o público ou, em outros termos, os laços entre o cuidado de si e o cuidado com o outro, Rorty precisaria reavaliar sua sentença a respeito de Foucault: seria ele realmente apenas útil do ponto de vista privado ou, como seu colega Habermas e seu ídolo Dewey, poderia ser muito útil à sociedade democrática? Redescrito de um novo ângulo, Foucault pode ser visto como o ironista liberal elogiado por Rorty, a despeito de ele não ser, tecnicamente falando, nem ironista, nem liberal. ${ }^{10}$

${ }^{10}$ Ao contrário do que Rorty (1999a) sugere, a relação entre o cuidado de si e o cuidado do outro não tem nada a ver com o fato de Foucault querer atrelar sua autonomia individual nas instituições. 
Na sequência de nosso exercício redescritivo, gostaríamos de discutir os (ab)usos que, segundo Rorty, a esquerda de seu país teria feito da filosofia de Foucault, redescrevendo-os quando possível.

Uma das consequências da presença de Foucault nos departamentos americanos se referiria àquilo que Rorty (2000) nomeou de sobrefilosoficação da politica, estratégia que teria substituído o reformismo e o pragmatismo da velha esquerda por um academicismo inútil, radical e, na pior das hipóteses, ressentido. Não conseguimos encontrar motivos para esse tipo de interpretação, quando tomamos a obra de Foucault em análise. Algumas vezes o vimos nos alertando para não confundir aquilo que ele fez em seus livros com sua maneira de abordar as questões políticas, pois haveria pouca "[...] ligação 'analítica' entre uma concepção filosófica e a atitude política concreta daquele que a sustenta" (FOUCAULT, 2004a, p. 219). Essa, aliás, é uma recomendação que o próprio Rorty advoga em relação ao seu trabalho. Em outras passagens, nós o vimos dizendo que a "[...] Filosofia já foi abolida. Ela não passa de uma vaga disciplina universitária, na qual as pessoas falam da totalidade da entidade, da 'escritura', da 'materialidade significante' e de outras coisas semelhantes" (FOUCAULT, 2006, p. 295). Isso também não soa bem rortiano? Em tantas outras, notamos seu apelo para que se faça da reflexão filosófica um instrumento de compreensão de nosso presente, uma vigia dos abusos da racionalidade política em voga. Essa função crítica da filosofia decorria, até certo ponto, "[...] do imperativo socrático: 'Ocupate de ti mesmo', ou seja: 'Constitua-te livremente, pelo domínio de ti mesmo" (FOUCAULT, 2004a, p. 287). Trata-se, portanto, de encarar a filosofia como uma crítica da razão política, algo da ordem de um contrapoder permanente. No entanto, não conseguimos encontrar, em seus livros, uma sentença que denotasse a importância, tal como sugerido por Rorty, da filosofia como fundamento da política, como disciplina que ofereceria um quadro teórico a possibilitar aos indivíduos esboçar, programar ou legislar suas utopias políticas.

Ao contrário, pensamos que, do ponto de vista político, Foucault era um não academicista, um prático, porque concebeu a política como uma forma de se colocar no mundo e, se for o caso, lutar para transformá-lo. Em outras palavras, a política pressupõe, em Foucault, um tipo de intervenção distinto das intervenções livrescas e teóricas, sendo mais da ordem de um engajamento pessoal e físico: "Se eu luto por tal questão ou por tal outra, eu o faço porque, de fato, essa luta é importante para mim, em minha subjetividade" (FOUCAULT, 2006, p. 344). Ou, então: “A

O motivo para pensarmos assim é que uma atitude como essa contraria o espírito do filósofo, que escrevia para esquecer, para não ter um rosto. Como poderia, então, almejar encarnar sua autonomia privada, em uma instituição? Como poderia desejar uma forma de moralidade a que todos deveriam se submeter, se ele próprio (2004a) considerou essa busca catastrófica? 
chave da atitude política pessoal de um filósofo não deve ser buscada em suas ideias, como se pudesse delas ser deduzida, mas, sim, em sua filosofia como vida, em sua vida filosófica, em seu êthos" (FOUCAULT, 2004a, p. 219). Pensamento e ação política (teoria e prática) estariam ligados da maneira ética, como uma prática refletida em busca incessante pela liberdade. Essa é uma interpretação bem distinta daquela que associa a esquerda foucaultiana à obsessão cientificista e teórica, bem como da interpretação segundo a qual tal esquerda busca uma conexão estreita demais entre a política e a filosofia (sociologia, teoria literária etc.).

No que diz respeito ao seu suposto antirreformismo, que tanto mal teria feito à esquerda americana, não é que Foucault fosse contrário às reformas propriamente ditas, porém, preferiu se engajar nas lutas políticas de uma forma "desprogramada", apostando na invenção e na singularidade da situação do momento em questão. Talvez isso tenha irritado Rorty, pois as reformas resultam não tanto de um movimento "de cima para baixo", do "governo para o povo", do "político para o cidadão comum", mas, por um lado, de uma transformação real nas maneiras de pensar e, por outro, das tensões, dos conflitos, das lutas que dela decorrem. Uma reforma nunca é senão o resultado de um processo no qual há conflito, afrontamento, luta, resistência, desestabilização sem fim. Ela é apenas o perfil provisório de uma nova relação de forças. Quando a experimentação e a desterritorialização cessam de acontecer, quer dizer, quando a problematização deixa de se colocar, a "reforma" se faz lei e, por consequência, tem-se uma proibição de inventar, na medida em que se estabiliza um sistema de poder ao final de certo número de mudanças (FOUCAULT, 2004a). Uma reforma concebida desse modo está realmente menos preocupada com as "[...] leis que precisam ser aprovadas do que sobre uma cultura que precisa ser mudada.” (RORTY, 1999c, p. 114). Não significa, como disse Rorty (1999c), que seja sem finalidade, isenta de consciência política:

Mas uma das realizações dos anos sessenta e setenta - que considero como realizações benéficas - é que certos modelos institucionais têm sido experimentados sem programas. Sem programa não quer dizer cegamente - enquanto cegueira de pensamento. Na França, por exemplo, nos últimos tempos, se tem criticado bastante o fato de que os diferentes movimentos políticos em favor da liberdade sexual, das prisões, da ecologia, etc., não tenham programa. Mas, penso, não ter programa pode ser ao mesmo tempo, muito útil, muito original e muito criativo, se isso não quer dizer não ter reflexão real sobre o que acontece ou não se preocupar com o que é impossível. Desde o século XIX, as grandes instituições políticas e os grandes partidos políticos confiscaram o processo de criação política, quero dizer com isso que eles têm tentado dar à criação política a forma de um programa político, com a finalidade de se apoderar do poder. Penso que é necessário preservar o que se produziu nos anos sessenta e no início dos anos setenta. Uma das coisas que é preciso preservar, creio, é a existência, fora dos grandes partidos políticos, e fora do programa normal ou comum, uma certa forma de inovação política, de 
ALMEIDA, F. Q.; VAZ, A. F.

\begin{abstract}
criação política e de experimentação política. É um fato que a vida cotidiana das pessoas tem mudado entre o início dos anos sessenta e agora; minha própria vida é testemunho disso. Evidentemente, não devemos essas mudanças aos partidos políticos, mas aos numerosos movimentos. Esses movimentos têm verdadeiramente transformado nossas vidas, nossa mentalidade e nossas atitudes, assim como as atitudes e a mentalidade de outras pessoas - as pessoas que não pertencem a esses movimentos. E isso é algo de muito importante e muito positivo. Eu repito, não são essas velhas organizações políticas tradicionais e normais que permitem esse exame. (FOUCAULT, 1982, s/p).
\end{abstract}

Enquanto Rorty viu, nesses movimentos dos anos 1960 e 1970, o recuo da esquerda reformista, Foucault os concebeu como uma oportunidade para se conseguir aquilo que o próprio colega americano desejava: que as pessoas, pouco importa se gays, lésbicas, heterossexuais, negras, brancas, mexicanos ou americanos, "[...] fossem livres para construir sua vida, de forma bem nietzschiana" (RORTY, 2006, p. 43). A diferença entre eles, portanto, era de como levar a cabo esse objetivo, pois, ao contrário de Rorty, Foucault não quis enquadrar essa política da individualidade (RORTY, 2006) no seio de uma narrativa identitária mais ampla, do tipo: "todos nós, em nossas diferenças, somos iguais, porque somos americanos". Foucault recusou essa alternativa etnocentrista, elaborada em torno da ideia de uma política patriótica, uma vez que não quis pensar em si mesmo falando como integrante de um "nós" qualquer, do tipo "nós, os homossexuais" ou, então, "nós, os franceses". Mais importante do que a defesa e a afirmação de identidades, pouco importa se restrita a um grupo sexual, racial ou a toda uma Nação, ele acreditava que nós tínhamos que nos afirmar como forças criativas. Sua preocupação, por conseguinte, não era tanto ser identificado com um movimento ou com uma política identitária (a homossexual, a prisional, a ecológica ou, no caso de Rorty, o "povo" americano), mas ele queria, isso sim, ocupar-se com a questão do modo de vida, com a técnica de si, no sentido de saber como definir-se para si mesmo. "Eu quero poder fazer as coisas que me dão vontade e, aliás, é o que eu faço. Mas não me peça para proclamá-las" (FOUCAULT, 2006, p. 339), ou seja, para ser identificado por elas ou, no extremo, elaborar uma política (identitária) a partir delas. Rorty, é óbvio, não aceitou isso, pois essa força criativa, um devir plural, um movimento sem lei, pôs em cena uma espécie de preocupação estética que, se entendemos a crítica dele a Foucault, poderia revelar-se perigosa à solidariedade social, na medida em que deixava de ser o que ela deveria ser: uma necessidade meramente privada. Isto é, reaparece, a esse respeito, o infundado receio que ele já tinha manifestado em relação à "ironia" foucaultiana: a pretensa indiferença social de seu modelo estético da existência, do cuidado de si, uma atitude que pode fazer da constante criação, inovação e experimentação privada de seu modo de vida algo mais importante do que evitar a crueldade. $O$ fato de esse modo de 
vida poder dar lugar a uma série de relações sociais e mesmo a uma ética passou despercebido a Rorty, em mais essa leitura da filosofia de Foucault.

Finalizamos nossa redescrição, aludindo à ideia segundo a qual as políticas culturais que se tornaram predominantes na América, após a década de 1960, no afã de valorizarem o estigma e a diferença, deixaram de fazer o que, para Rorty, era fundamental já naquele momento: a crítica da economia política em voga. Foram, assim, responsáveis pelo ocaso das preocupações econômicas (dinheiro e mercado de trabalho), no seio das lutas políticas. Quanto a isso, gostaríamos de encerrar com três rápidos comentários.

Rorty tem uma relação ambígua com o determinismo econômico da velha esquerda americana, pois, ao mesmo tempo em que o crítica, ele defende posições segundo as quais a falta de sensibilidade em relação à diferença, ao outro ou às minorias, mostrar-se-ia como subprodutos da injustiça econômica. ${ }^{11} \mathrm{O}$ retorno da luta de classes ("[...] é o patrão quem deve ser combatido como inimigo") como motor da política é uma tentativa de fazer novamente da economia política o requisito essencial para a participação nas iniciativas de esquerda, no seio da sociedade globalizada.

Em segundo lugar, precisaríamos saber até que ponto os escritos de Foucault teriam realmente motivado o esquecimento da crítica econômica, no discurso da esquerda americana. Se isso, de fato, aconteceu, Foucault não pode ser diretamente responsabilizado por esse acontecimento, não só porque ele não é responsável pelos (ab)usos que se fizeram dos seus escritos, mas porque, seguindo um ensinamento do próprio Rorty, não devemos olhar para um autor e procurar uma conexão muito estreita entre seu trabalho (filosófico, sociológico, histórico etc.) e suas posições políticas. Todavia, não é exatamente isso que Rorty faz, em relação a Foucault? O fato de ele dizer que Foucault é um filósofo útil para a transformação privada e inútil para a vida pública não expressa esse tipo de atitude? A esquerda teria se transformado em "ressentida" e "desesperançosa", ao invés de permanecer reformista, porque o trabalho filosófico e histórico de Foucault tinha esse caráter?

Em terceiro lugar, se Rorty tivesse permanecido mais atento à letra filosófica do seu colega francês, talvez pudesse "jogar" Foucault contra seus próprios admiradores, na esquerda americana, alertando-os de que, também nele, a análise da economia política em curso não estava ausente, sobretudo porque a

${ }^{11} \mathrm{O}$ resultado desse economicismo pode ser visto na maneira unilateral e reducionista com a qual Rorty interpretou as políticas centradas na identidade ou na diferença. Deixou de considerar, assim, como essas políticas foram de grande utilidade para se diminuir o sofrimento e a crueldade de muitos, na sociedade democrática. 
crítica ao (neo)liberalismo como forma de governo, ou seja, a crítica à regra da economia como máxima de uma política da verdade, não escapou à sua analítica do (bio)poder. É evidente que a crítica de Foucault ao (neo)liberalismo não seguiu os passos de uma "domestificação do capitalismo", nem defendeu o retorno da luta de classes no âmbito de uma sociedade que, para Rorty, não tem por que superar o quadro de uma economia de mercado. Foucault recusou o (neo) liberalismo pois, diferentemente do seu colega norte-americano, essa forma de governo não foi, para ele, tanto uma solução quanto o indício de uma crise (ou de um limite crítico) no seio do que ele chamou de governamentalidade. Essa diferença produziu entre os dois avaliações bem distintas da sociedade liberal. Enquanto Rorty identificou no governo liberal, em especial nos Estados de BemEstar Social, a "melhor" medida até hoje alcançada entre a liberdade individual e a segurança social, a forma mais avançada de organização da solidariedade social para evitar o "a menos" de liberdade, ocasionado por uma economia regulada pelo mercado, ${ }^{12}$ Foucault (2008b) se "limitou" a diagnosticar todas as reavaliações e reestimações que desembocaram naquela forma específica de Estado (de governo) como produtos (ou vítimas) das crises da governamentalidade liberal, situando-as no quadro biopolítico da modernidade.

Foucault (2008, p. 94) desconfiava se as políticas intervencionistas do Estado na economia “[...] acaso não introduzem sub-repticiamente tipos de intervenção, acaso não introduzem modos de ação que são, eles próprios, pelo menos tão comprometedores para a liberdade quanto essas formas políticas visíveis e manifestas que se quer evitar?". Rorty recusou essa "cultura do perigo", vendo nas políticas de Keynes ou de Roosevelt não ameaças de um novo despotismo, mas avanços concretos e práticos em favor da solidariedade, contra a crueldade e o sofrimento humano. ${ }^{13}$ Não surpreende ter "cobrado" de Foucault uma avaliação mais positiva daquele Estado. Foucault, por sua vez, opôs à moderação do intelectual liberal (o etnocentrismo de Rorty) a necessidade de um hiperativismo crítico do liberalismo, algo da ordem do que ele chamou de uma ontologia crítica de nosso presente histórico, uma prova prática dos limites que precisamos ultrapassar, "[...] um trabalho paciente que dá forma à impaciência da liberdade"

\footnotetext{
${ }^{12}$ Para usar a terminologia foucaultiana, Rorty não viu problemas ou perigos no paradoxo identificado por Foucault a respeito da arte de governar liberal: ao mesmo tempo em que sua razão governamental precisa da liberdade, produzindo-a, é obrigada também a organizá-la, gerindo-a. O jogo entre liberdade e segurança é o que está no âmago dessa nova razão governamental. Na filosofia de Rorty, esse jogo corresponde à relação entre a ironia e o liberalismo, entre o público e o privado. O ironista liberal é a síntese perfeita dessa ambiguidade, abraçada e celebrada por Rorty.

${ }^{13}$ Da mesma maneira que ele (1999d) se indagou "Por que Marx e não Keynes", também quis que a esquerda de seu país permanecesse deweyana ou se transformasse em habermasiana, jamais foucaultiana.
} 
(FOUCAULT, 2005, p. 351). Essa atitude de interrogar nossa própria atualidade escapa à imputação de reformismo, parecendo muito mais um convite para o incessante trabalho de interrogar a racionalidade política que regula o liberalismo atual, com o intuito de evitar ser excessivamente governado pelos dispositivos biopolíticos que garantam o funcionamento dessa forma de organização social. A libertação, como ultrapassagem das linhas de crise que atravessam um sistema, suas "fronteiras", tal é, para Foucault, a atitude política que se deve tentar realizar. Como se vê, uma aposta muito diferente do reformismo nacionalista e patriótico acalentado por Rorty.

\section{CONSIDERAÇõES FINAIS}

Para desenvolver a interlocução proposta neste artigo, assumimos uma estratégia comum ao estilo filosófico de Rorty, quer dizer, a redescrição. ${ }^{14}$ Como ele próprio disse, muito do que escreveu encontrou sua motivação na redescrição daquilo que os outros escreviam, pouco importa se a respeito dele ou não. Em nosso exercício, primeiro tivemos que apresentar, com Rorty, o que ele viu na obra de Foucault e na recepção deste pela esquerda norte-americana. Após isso, cotejamos essa interpretação com a nossa própria, redescrevendo, contra Rorty, sua interpretação da filosofia foucaultiana. O objetivo, é evidente, não foi oferecer uma leitura mais "verdadeira" do trabalho deste último, mas uma descrição alternativa que reunisse "chamadas de atenção" para aspectos que parecem ter passado despercebidos ao filósofo norte-americano.

No caso de redescrição que oferecemos, faltou a Rorty maior atenção aos deslocamentos operados por Foucault em sua obra, sobretudo quanto ao conceito de poder. Escapou a ele, ainda, o fato de o filósofo francês não poder ser considerado um autor ironista, pois há entre a "ironia" e o seu correlato "cuidado de si" uma diferença importante: o fato de uma se resumir à esfera privada e a outra implicar uma relação social. Nossa redescrição do poder e da ironia nos faz pensar que Rorty se equivocou, ao dizer que, entre ele e Foucault, somente há diferenças políticas, e não teóricas.

Em defesa de Rorty, contudo, poder-se-ia afirmar que ele tinha um conhecimento relativamente restrito das obras do chamado "último" Foucault. Esse "desconhecimento", decerto, nos coloca em uma situação mais privilegiada do que

${ }^{14}$ Mais do que um método rigoroso ou conceito bem delimitado, interpretamos a redescrição em Rorty como uma estratégia segundo a qual a filosofia seria uma conversação edificante, em que os filósofos se redescrevem uns aos outros, comparando seus vocabulários entre si, na expectativa de persuadir seus interlocutores em favor de uma descrição (ou de um vocabulário) que seria mais atraente. Empregamos aqui a estratégia rortiana "contra" ele próprio. 
a dele, para uma interpretação; senão mais precisa, ao menos um pouco mais justa do pensamento político de Foucault (embora pudéssemos replicar: na verdade, tais obras de Foucault foram publicadas com Rorty ainda vivo; ele teve, portanto, a oportunidade de rever suas posições a respeito de Foucault, o que não foi feito).

Quanto às suas divergências políticas, essas são indubitáveis. Suspeitamos, porém, se Foucault pode ser responsabilizado pelo ocaso da esquerda reformista e programática da América, especialmente porque, ao se imputar isso a ele, Rorty faz com seu colega aquilo que não admite para si próprio: uma associação muito estreita entre a sua filosofia e suas predileções políticas. Se a filosofia não deveria, para Rorty, fundamentar a política, mas, sim, expressar as esperanças políticas de uma comunidade ou, no caso dele, do povo americano, talvez isso explique por que Foucault foi tão bem aceito entre os esquerdistas americanos, a ponto de provocar uma ruptura no seio daquela tradição, em seu país.

Por fim, e se tomarmos a discussão sobre o cuidado de si, vemos Foucault situar a filosofia no terreno do modo de vida, da arte de viver e de exercício da espiritualidade; portanto, não como disciplina nem tampouco como teoria que, por exemplo, fundamenta a política. Essa outra perspectiva não apenas refutaria a possível acusação rortiana de sobrefilosoficação, como possibilitaria, ao contrário, encontrar elementos comuns na maneira pela qual ambos compreendem a própria filosofia.

ALMEIDA, F. Q.; VAZ, A. F. (Re)describing Foucault: with Rorty, against Rorty. Trans/ Form/Ação, Marília, v. 34, n.2, p. 193-214, 2011.

ABSTRACT: This paper aims to put in dialog the French Philosopher Michel Foucault and the North-American Philosopher Richard Rorty. It presents Rorty's lecture of Foucault's work and analyses this interpretation. After that, the paper offers an alternative interpretation of Foucault's work, suggesting that Rorty was quite imprecise in his interpretation A final commentary about this conversation.

KEYWORDS: Rorty. Foucault. Philosophy. Politics.

\section{REFERÊNCIAS}

COSTA, J. F. O sujeito em Foucault: estética da existência ou experimento moral. Tempo Social - Revista de Sociologia da USP, São Paulo, v. 1-2, n. 7, p. 121-138, out. 1995.

FOUCAULT, M. Michel Foucault, an interview: sex, power and the politics of identity. Entrevista concedida a B. Gallagher e A. Wilson, em junho de 1982. Tradução de Wanderson Flor do Nascimento. The advocate, Toronto, n. 400, p. 26-30 e 58, 7 de agosto de 1984. 
. O sujeito e o poder. In: DREYFUS, H.; RABINOW, P. (Org.). Michel Foucault: uma trajetória filosófica: para além do estruturalismo e da hermenêutica. Rio de Janeiro: Forense Universitária, 1995. p. 231-249.

História da sexualidade I: a vontade de saber. Rio de Janeiro: Graal, 1997.

Ditos e escritos: ética, sexualidade, política. Rio de Janeiro: Forense Universitária, 2004a. v. 5.

A bermenêutica do sujeito: São Paulo: Martins Fontes, 2004b.

Ditos e escritos: arqueologia das ciências e história dos sistemas de pensamento. Rio de Janeiro: Forense Universitária, 2005. v. 2

Ditos e escritos: problematização do sujeito: psicologia, psiquiatria e psicanálise. Rio de Janeiro: Forense Universitária, 2006. v. 1.

Segurança, território e população. São Paulo: Martins Fontes, 2008a.

O nascimento da biopolitica. São Paulo: Martins Fontes, 2008b.

MARSHALL, J. On what we may hope: Rorty on Dewey and Foucault. Studies in Philosophy and Education, New York, v. 13, n. 3-4, p. 307-323, Sept. 1994.

RORTY, R. A filosofia e o espelho da natureza. Rio de Janeiro: Relume-Dumará, 1994.

Objetivismo, relativismo e verdade. Rio de Janeiro: Relume-Dumará, 1997.

Ensaios sobre Heidegger e outros: escritos filosóficos 2. Rio de Janeiro: RelumeDumará, 1999a.

Consequências do pragmatismo. Lisboa: Instituto Piaget, 1999b.

Para realizar a América: o pensamento de esquerda no século XX na América. Rio de Janeiro: DP\&A, 1999c.

Philoshophy and social hope. London: Penguin Books, 1999d.

The overphilosophication of politics. Constellations, Malden, v. 7, n. 1, p. 128-132, 2000.

Verdade e progresso. Barueri: Manole, 2005.

Contra os patrões, contra as oligarquias: uma conversa com Richard Rorty. São Paulo: UNESP, 2006.

Contingência, ironia e solidariedade. São Paulo: Martins Fontes, 2007.

Recebido em: 2 de março de 2011

Aprovado em: 5 de maio de 2011

Trans/Form/Ação, Marília, v. 34, n. 2, p. 193-214, 2011 